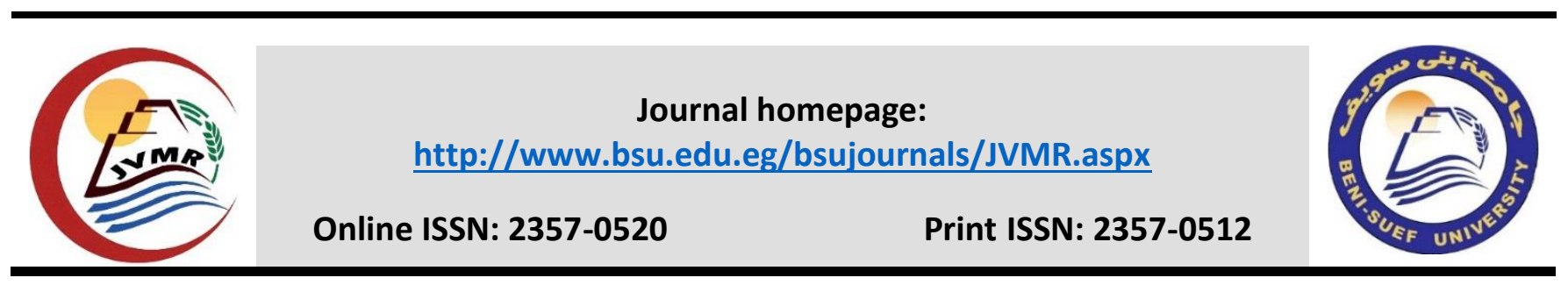

Original Research Article

\title{
Vaccination against some $E$. coli Serotypes Isolated from Diseased Broiler Chickens with Chronic Respiratory Disease (CRD)
}

\author{
Al Hussien M. Dahshan ${ }^{a}$ and Asmaa A. Mohamed \\ ${ }^{a}$ Department of Poultry Diseases, Faculty of Veterinary Medicine, Beni-Suef University Beni Suef 62511, Egypt \\ ${ }^{\mathrm{b}}$ Veterinary supervisor animal production, Faculty of Agriculture, Al-Mina University
}

\section{ABSTRACT}

Broiler chickens are frequently infected with Escherichia coli (E.coli), which often results in disease and high economic losses. Poultry of all ages are susceptible to infections with E.coli, but the most affected are birds of 4-5 weeks. In our study Serotypes $\mathrm{O}_{78}$ and $\mathrm{O}_{187}$ were chosen as they were the most prevalent isolated serotypes from diseased broiler chicken with respiratory affections specially CRD, one hundred chicks of different ages, sex and breeds (cobb, native, sasso) were used in this study. The samples were collected from privately owned poultry farms at EL Mina, Fayoum, Giza and Beni-Suef governorates, all sampled chicks showed clinical signs characteristic for $E$. coli affections including respiratory distress with or without diarrhea, Swabs from internal organs of 60 diseased chicks were subjected to bacterial examination. Out of 53 oxidase negative strains, $40 \mathrm{E}$. coli isolates were recovered, other Enterobacteriaceae including, Proteus vulgaris and Pseudomonas aeruginosa. Out of 40 E.coli isolates, E. coli $\mathrm{O}_{78}$ was the most predominant serotype isolated (23) with an incidence of $57.5 \%$ followed by $E$. coli $\mathrm{O}_{187}(12)$ isolates with an incidence of $30 \%$ and $E$. coli $\mathrm{O}_{115}$ (5) isolates at percentage of $12.5 \%$, The pre-prepared vaccine against $E$.coli serotype $\mathrm{O}$ used in this study was designed vaccine as it contains an $E$. coli strain that has been genetically-modified by the deletion of the aroA gene responsible for the biosynthesis of amino acids in the virulent E. coli parent strain (The GMO is named aroA- PTA-5094). The aroA gene-deleted vaccine can trigger a protective immunity in poultry against infection and disease from wild, virulent $E$. coli bacteria found in the environment. However, because the aroA gene is deleted, the live vaccine bacterium becomes a-virulent and unable to form a self-sustaining population since the vaccine strain has lost the capability to synthesize the amino acids necessary for its survival. The $E$. coli vaccine dosages were calculated according to a titer of $5.0 \times 10^{6} \mathrm{cfu}$ per dose, one hundred one day old chicks were divided into 5 groups each one 20chicks,group 1, control negative and groups 4 and 5 control positive for serotype $\mathrm{O}_{78}$ and serotype $\mathrm{O}_{178}$, while group 2 vaccinated at one day and challenged with E.coli $\mathrm{O}_{78}$ at age of 25 day old, also group 3 vaccinated at 5 day old and challenged with E.coli $\mathrm{O}_{178}$ at age of 25 day old, Two findings, the average lesion scores of air sacs in the groups 4 and 5, four and 3 birds died in the positive control at two days post challenge with $E$. coli $\mathrm{O}_{78}$ and $\mathrm{O}_{178}$ respectively. The birds were found

\section{ARTICLE INFO}

Article history:

Received: 112016

Accepted: 122016

Available Online: 122016

Keywords:

Broiler chicks, vaccination,

E.coli 
to have acute, severe septicemia and $E$. coli could be isolated from the livers. The mortality and morbidity rates of the birds vaccinated with $E$. coli aroA-live vaccine was great better significant difference from the positive control group showing no mortalities and low pathological picture. There were significant differences in the FCR among the 3 groups significantly less than those of the positive control groups; the body weight was higher in vaccinated groups. Our conclusion, vaccination improves health and FCR and ABW of broiler chicks.

* Corresponding author: Al-Hussien., M. Dahshan, Department of poultry diseases Faculty of Veterinary Medicine, Beni-Suef University, Beni-Suef 6511, Egypt. , Tel.: +201005660727.

E-mail: hussiendahshan73@vet.bsu.edu.eg

\section{Introduction}

Chronic respiratory disease of chickens (CRD) is a serious respiratory infection that is difficult or impossible to cure, has been complicated by fibrinous perihepatitis, pericarditis, and aerosacculitis. Pathogenic E.coli (APEC) infection occurs as an acute fatal septicemia or subacute pericarditis and airsacculitis, as well as perihepatitis, arthritis, and cellulitis with loses ranges from one to 30 percent, the disease can occur in any age group but usually occurs between 4 and 8 weeks of age. Salpingitis, peritonitis and hypopyon have been observed in association with the pericarditis. Escherichia coli were isolated from 22 of 22 birds with pericarditis. Various bacteria and other diseases are associated with Pericarditis. In most studies the common serotypes have been O1, O2, O35, and O78 (Sojika et al., 1965; Heller et al., 1977; Chansiripornchai and Sasipreeyajan, 2002). E. coli vaccines are an alternative way to prevent and control of E. coli infection due to the high frequency of resistance to antibiotics used in treatment of $\mathrm{E}$. coli in farms, E. coli vaccines include an inactivated vaccine, a live attenuated vaccine and a recombinant vaccine. Effective inactivated vaccines against various serotypes, including $\mathrm{O} 2: \mathrm{K} 1$ and O78:K80 have been produced (Deb and Harry, 1976; Deb and Harry, 1978; Cessi, 1979), Recently, a commercial live vaccine for chickens has been developed The Poulvac ${ }^{\circledR}$ E. coli vaccine contains an E. coli strain that has been genetically-modified by the deletion of the aroA gene responsible for the biosynthesis of amino acids in the virulent E. coli parent strain (The GMO is named aroA- PTA-5094). The aroA gene-deleted vaccine is capable of triggering a protective immunity in poultry against infection and disease from wild, virulent E. coli bacteria found in the environment. However, because the aroA gene is deleted, the live vaccine bacterium is avirulent and unable to form a selfsustaining population since the vaccine strain has lost the capability to synthesize the amino acids necessary for its survival, the E. coli aroA-live vaccine can protect against the homologous and heterologous serogroups. The objective of our study was to prove the efficacy of the $E$. coli aroA-live vaccine against $E$. coli serotypes $\mathrm{O} 78$ and $\mathrm{O} 178$.

\section{Materials and methods}

\section{1. samples:}

One hundred samples were collected from chicks of different ages, sex and breeds (cobb, native, sasso) from privately owned poultry farms at EL Mina, Fayoum, Giza and Beni-Suef governorates, all sampled chicks showed clinical signs characteristic for $E$. coli affections including respiratory distress with or without diarrhea, Swabs from internal organs of 50 diseased chicks were subjected to bacterial examination. 


\subsection{Chickens}

One hundred unvaccinated apparent healthy one day old chicks were divided into 5 groups each one 20chicks. The used chicks will be floored reared and fed on a balanced commercial ration; the chickens were fed ad libitum before and during the experiments.

\subsection{Bacteriological examination:}

\subsubsection{Isolation of bacterial agents:}

The samples from internal organs (heart, liver and intestine) were collected, Using different selective and differential media including Tryptone soya broth and tetrathionate broth then incubated at $37^{\circ} \mathrm{C}$ for 18-24 hours plating onto (MacConkey's, , Eosin Methylene Blue, Tryptone soya agar and XLD medium) and incubated at $37{ }^{\circ} \mathrm{C}$ for $18-24$ hours.2.4. Post mortem examination

\subsubsection{Morphological examination}

According to Cruickshank et al, (1975)

\subsubsection{Biochemical identification:}

The pure colonies of isolates were identified biochemically according to Quinn et al. (2002); Koneman et al. (1995) and Finegold and Martin (1982).

\subsection{Detection of virulence factors:}

Congo red binding test and haemolytic activity were performed for differentiation of pathogenic and nonpathogenic bacterial isolates also for differentiation between haemolytic and non haemolytic isolates according to (Berkhoff and Vinal, 1986).

\subsection{Serological identification of $E$. coli:}

Isolates that were preliminary identified biochemically as E.coli were subjected to serological identification according to Ewing (1986).

\subsection{Vaccination and Experimental designs}

\subsubsection{Vaccine:}

Poulvac ${ }^{\circledR}$ E. coli vaccine (Fort Dodge Animal Health, Iowa, USA) contains an E. coli strain that has been genetically-modified by the deletion of the aroA gene responsible for the biosynthesis of amino acids in the virulent $E$. coli parent strain (The GMO is named aroA- PTA-5094). Was orally administered to the chickens according to the manufacture's recommendation, The E. coli vaccine dosages were calculated according to a titer of $5.0 \times 10^{6} \mathrm{cfu}$ per dose.

\subsubsection{Experimental designs}

-Group 1 control negative group for both serotypes O78 and 0178 and groups 4 and 5 kept as control positive for serotype $\mathrm{O} 78$ and serotype $\mathrm{O} 178$ respectively, while group 2 vaccinated and challenged with E.coli virulent $\mathrm{O} 78$ strain (homologous challenge), also group 3 vaccinated and challenged with E.coli O178 virulent strain (homologous challenge) .

-Group 2 and group 3 were vaccinated at 5 days old orally with Poulvac ${ }^{\circledR}$ E. coli vaccine, The E. coli vaccine dosages were calculated according to a titer of $5 \times 10^{6}$ cfu per dose.

- Before inoculation, random samples consisting of tracheal swabs were subjected bacteriological examinations which proved to be healthy and free from any pathogenic E.coli.

- $0.5 \mathrm{ml}$ of the E. coli suspension, containing $3 \times 10^{8}$ cfu/ml of E. coli $\mathrm{O} 78$ according to McFarland standard reactions was used for intratracheal challenge at 25 days of age.

$-0.5 \mathrm{ml}$ of the E. coli suspension, containing $3 \times 10^{8}$ $\mathrm{cfu} / \mathrm{ml}$ of E. coli O178 according to McFarland standard reactions was used for intratracheal challenge at 25 days of age.

- At 7 days post challenge, the total number of dead birds was noted, and all the surviving birds were necropsied and examined for the presence of grossly visible lesions of Colibacillosis.

\subsubsection{Parameters evaluated}

A-Morbidity and mortality rates were calculated

B-The pericardial and perihepatic lesions of colisepticemia in each bird were scored. The pericardial lesions of colisepticemia were scored according to (Charleston et al. 1998) as follows: 0 : no visible lesions, 1: definite fibrination on the surface of the liver, 2: extensive fibrination, adhesions, liver swelling and necrosis. Chickens with severe lesions were characterized as having a pericarditis and perihepatitis scores of either 1 or 2 .

C- The average body weight of the birds in each group was measured at 7 day, 14 days, 21 days, 28 days and 35 days of age.

D- A feed conversion ratio (FCR) was calculated for each group by taking the total amount of feed consumed by each group between days 


\section{Results}

\subsection{Bacteriological examination}

Out of 100 cases 60 (60\%) were positive with bacterial isolates, 53 positive for Enterobacteriaceae, out of 53 oxidase negative strains, $40(75.4 \%)$ E. coli isolates were recovered, 13(24.52\%) (Table1). Other Enterobacteriaceae including Proteus vulgaris and Pseudomonas aeruginosa, E. coli $\mathrm{O} 78$ was the most predominant E.coli isolates, (23) out of 40 E.coli isolates with an incidence of $57.5 \%$ followed by $E$. coli $\mathrm{O} 187$ (12) isolates with an incidence of $30 \%$ and E. coli O115 (5) isolates at percentage of $12.5 \%$ (Table 2)

in the vaccinated groups (2 and 3) with E. coli aroAlive vaccine. For, the average lesion scores of air sacs in the groups vaccinated with E. coli aroA-live vaccine

each group were revealed the improvement of the pathological lesions in vaccinated groups 2 and 3 in comparison with the control positive groups. were recorded. There was a significant difference in the FCR among the 4 groups significantly less than those of the positive control groups (Table 3) and the histopathological examination of liver sections for Two chicks died in the positive control groups 4 and 5 two days post challenge with E. coli O78, O178 respectively. The postmortem examination were severe septicemic picture and E. coli reisolated from the liver. No mortality and low morbidity rates in the

Table 1. the overall bacterial isolation from diseased chicks with respiratory signs

\begin{tabular}{|lcc|}
\hline Bacterial isolation from chicks & Number & Percentage \\
\hline Bacterial isolates /100 & 60 & $60 \%$ \\
\hline Enterobacteriaceae isolates /60 & 53 & $88.3 \%$ \\
\hline E.coli isolates /53 & 40 & $75.4 \%$ \\
\hline Other Enterobacteriaceae / 53 & 13 & $24.5 \%$ \\
\hline Negative isolation / 100 & 40 & $40 \%$ \\
\hline
\end{tabular}

\subsection{Experimental infection}

\section{Table 2. Serogroups of E. coli isolated from different organs of diseased birds}

\begin{tabular}{|lcc|}
\hline Serotype & Number / 40 & Percentage \\
\hline O78 & 23 & $57.5 \%$ \\
\hline O178 & 12 & $30 \%$ \\
\hline O115 & 5 & $12.5 \%$ \\
\hline
\end{tabular}




\begin{tabular}{|c|c|c|c|c|c|c|c|c|c|c|c|c|}
\hline \multirow[t]{3}{*}{ group } & \multirow{2}{*}{\multicolumn{2}{|c|}{ Morbidity }} & \multirow{2}{*}{\multicolumn{2}{|c|}{ Mortality }} & \multirow{2}{*}{\multicolumn{5}{|c|}{$\begin{array}{c}\text { Average body weight /week } \\
\pm \text { SD }\end{array}$}} & \multirow[t]{3}{*}{ FCR } & \multicolumn{2}{|c|}{ Lesion score } \\
\hline & & & & & & & & & & & & \\
\hline & NO. & $\%$ & $\mathrm{NO}$ & $\%$ & $1^{\mathrm{st}}$ & $2^{\text {nd }}$ & $3^{\text {rd }}$ & $4^{\text {th }}$ & $5^{\text {th }}$ & & $\begin{array}{l}\text { score } \\
\text { NO. }\end{array}$ & \\
\hline $1(n=20)$ & 0 & 0 & 0 & 0 & $\begin{array}{l}190 \pm \\
48\end{array}$ & $\begin{array}{l}405 \\
\pm 77\end{array}$ & $\begin{array}{l}765 \\
\pm 125\end{array}$ & $\begin{array}{l}1150 \\
\pm 201\end{array}$ & $\begin{array}{l}1770 \\
\pm 322\end{array}$ & 1.9 & 0 & 0 \\
\hline $2(n=20)$ & 2 & $10 \%$ & 0 & 0 & $\begin{array}{l}180 \\
\pm 41\end{array}$ & $\begin{array}{l}400 \\
\pm 64\end{array}$ & $\begin{array}{l}751 \\
\pm 104\end{array}$ & $\begin{array}{l}1080 \\
\pm 145\end{array}$ & $\begin{array}{l}1650 \\
\pm 297\end{array}$ & 1.7 & $\begin{array}{c}1 / 2 \\
\text { Perihepatic } \\
\text { lesion }\end{array}$ & $50 \%$ \\
\hline $3(n=20)$ & 3 & $15 \%$ & 0 & 0 & $\begin{array}{l}183 \\
\pm 42\end{array}$ & $\begin{array}{l}408 \\
\pm 69\end{array}$ & $\begin{array}{l}745 \\
\pm 98\end{array}$ & $\begin{array}{l}1120 \\
\pm 125\end{array}$ & $\begin{array}{l}1580 \\
\pm 266\end{array}$ & 1.6 & $\begin{array}{c}1 / 3 \\
\text { Pericardial lesion }\end{array}$ & $33.3 \%$ \\
\hline $4(n=20)$ & 7 & $35 \%$ & $\begin{array}{l}2 / 2 \\
0\end{array}$ & $10 \%$ & $\begin{array}{l}187 \\
\pm 44\end{array}$ & $\begin{array}{l}208 \\
\pm 69\end{array}$ & $\begin{array}{r}390 \\
\pm 88\end{array}$ & $\begin{array}{l}645 \\
\pm 104\end{array}$ & $\begin{array}{l}860 \\
\pm 112\end{array}$ & 2.6 & $\begin{array}{l}\quad 5 / 7 \\
\text { extensive } \\
\text { fibrination in } \\
\text { liver and heart }\end{array}$ & $71.4 \%$ \\
\hline $5(n=20)$ & 8 & $40 \%$ & $\begin{array}{l}2 / 2 \\
0\end{array}$ & $10 \%$ & $\begin{array}{l}180 \\
\pm 42\end{array}$ & $\begin{array}{l}210 \\
\pm 69\end{array}$ & $\begin{array}{l}375 \\
\pm 74\end{array}$ & $\begin{array}{l}675 \\
\pm 110\end{array}$ & $\begin{array}{l}900 \\
\pm 125\end{array}$ & 2.4 & $\begin{array}{l}\quad 7 / 8 \\
\text { extensive } \\
\text { fibrination in } \\
\text { liver and heart }\end{array}$ & $87.5 \%$ \\
\hline
\end{tabular}

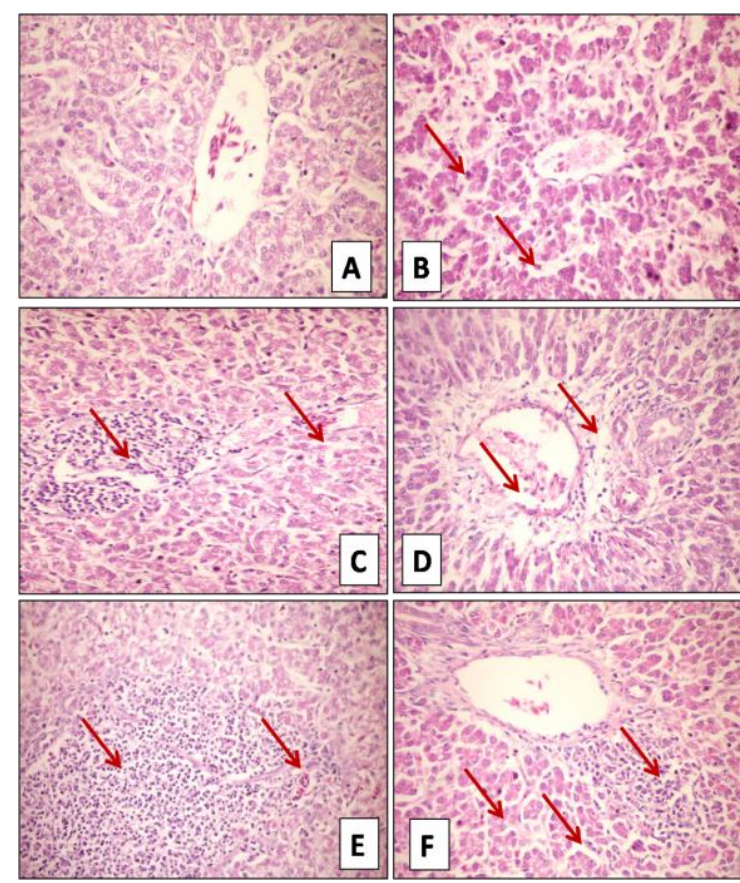

Figure 1.

A: apparently normal parenchyma. (Group 1)

B: focal area of necrosis infiltrated by mononuclear cells infiltration (Group 4).

$\mathrm{C}$ : focal area of necrosis infiltrated by mononuclear cells infiltration (Group 5).

D: slight portal tract congestion with slight leucocytic infiltration (Group 2).

E: slight portal tract congestion with slight leucocytic infiltration (Group 3).

F: leucocytic infiltration (Group 4).

\section{Discussion}

The majority of commercially produced poultry are known to have some E.coli with some strains inherently more pathogenic than others, and when mortality occur the bacteria is often implicated. Those strains causing disease, known as avian pathogenic E.coli (APEC), have developed adaptations enabling them to live outside the intestinal tract, leading to both localized and systemic manifestations of the disease. Most of these strains are pathogenic for poultry only and are responsible for the most common infectious bacterial disease of farmed poultry. The most common conditions include septicaemia, peritonitis airsacculitis and septicaemia complex in commercial broilers; in the current study the body performances of the chicks were evaluated in the concept of vaccination with $\mathrm{E}$. coli aroA-live vaccine, The results revealed that the vaccine tends to prevent $E$. coli infection. The vaccinated chickens in groups 2and3 tended to show lower morbidity and pathological findings including fewer airsacculitis, pericarditis, perihepatitis and peritonitis than the chickens in groups 4 and 5 than the chickens in the positive control group. While the FCR was significantly different in each group, 


\section{Conclusion}

It is concluded that PCR was the E. coli aroA-live vaccine tends to reduce the pathological lesions of the chickens challenged with $E$. coli serotypes $\mathrm{O} 78$ and $\mathrm{O} 178$

\section{Acknowledgements}

Great thanks for the staff of the Department of poultry diseases, Faculty of Veterinary Medicine, Beni-Suef University for the great effort during the entire practical section as well as the moral support.

\section{References}

Berkhoff, H. A. and Vinal, A. C. (1986): Congo red medium to distinguish between invasive and noninvasive Escherichia coli pathogenic for poultry. Avian Dis., 30(1): 117-121.

Cessi, D. (1979). Prophylaxis of Escherichia coli infection in fowls with emulsified vaccines. Clin. Vet. 102(4): 270-278.

Chansiripornchai, N. and Sasipreeyajan, J. (2002). Efficacy of sarafloxacin in broilers after experimental infection with Escherichia coli. Vet. Res. Comm. 26(4): 255-262.

Charleston, B., Gate, J.J., Aitken, I.A. Stephan, B. and Froyman, R. (1998). Comparison of the efficacies of three fluoroquinolone antimicrobial agents, given as continuous or pulsed-water medication, against Escherichia coli infection in chickens. Antimicrob. Agent Chemother. 42(1): 83-87.

Cruichshank, R.; Duguid, J.P.J; Marmion, B.P. and Swain, R.H.A. (1975): Medical Microbiology 12th ed. Velum II Churchill, living stone Edinburgh, London and New York.

Deb, J.R. and Harry, E.G. (1976). Laboratory trials with inactivated vaccines against Escherichia coli (O78:K80) infection in fowls. Res. Vet. Sci. 20(2): 131-138.

Deb, J.R. and Harry, E.G. (1978). Laboratory trials with inactivated vaccines against Escherichia coli (O2: K1) infection in fowls. Res. Vet. Sci. 24(3): 308-313.

Ewing, W.H. (1986): Identification of Enterobacteriacaea. 4th ed. Elsevier Science., New York.

Finegold, S.M. and Martin, W.T. (1982): Diagnostic microbiology. 6th ed.C.V. Mosby Company St. louis, Toronto.
Heller, E.D. and Drabkin, N. (1977). Some characteristics of pathogenic E. coli strains. Br. Vet. J. 133(6): 572-578.

Koneman, E.W.; Allen, S.D.; Janda, W.M.; Schrecken-berger, P.C. and winn, W.C. (1995): Introduction to Diagnostic Microbiology.

Quinn, P.J.; Carter,M.E.; Markey, B.K.; Donnelly, W.J.C. and Leonard, F.C. (2002):Veterinary Microbiology and Microbial diseases, Great Briian by MPG, Book. 1st ed., Bodmin, Cornwall, UK.

Sojka, W.J. (1965). Escherichia coli in Domestic Animals and Poultry. Commonwealth Agricultural Bureau: Farnham Royal, England. 